\title{
Zn AND K INFLUENCE IN FRUIT SIZES OF VALENCIA ORANGE ${ }^{1}$
}

\author{
VÍCTOR ANTONIO RODRÍGUEZ², SILVIA MATILDE MAZZA³, GLORIA CRISTINA MARTÍNEZ4, \\ ABEL RENÉ FERRERO
}

\begin{abstract}
In orange commercial farms, Zn deficiencies symptoms and small fruits were observed in Corrientes, Argentine. During four years (1995 to 1998), Valencia orange (Citrus sinensis Osb.) on Rough lemon (C. jambhiri Lush.) rootstock, implanted in 1974 in sandy soil, where six treatments were tested. Treatments varied from 1 to $3 \mathrm{Kg} \mathrm{KCl}_{\text {.tree }}{ }^{-1}$.year ${ }^{-1}$ (applied in April and December) with and without Zineb 80, 0,35\%. year ${ }^{-1}$, 20 L. tree ${ }^{-1}$ (13,3 $\mathrm{g} \mathrm{Zn} \cdot$ tree $^{-1}$ applied in December). The experimental design was a randomized complete block with four replications, with a single tree and borders in the experimental plot. Foliar sample were taken every year in Autumn and Summer, foliar concentrations of Zn and K were determined by atomic spectrum absorption. Harvested fruits were classified into small, medium and big. Analysis of Variance, Tukey test and Pearson correlations between production and foliar concentrations were performed. Higher fertilization levels of $\mathrm{K}$ with $\mathrm{Zn}$ increased medium and big fruits production (Kg and percentage). Foliar concentrations of $\mathrm{K}$ and $\mathrm{Zn}$ were positively correlated with big and medium fruit production and negatively correlated with small one. Chemical names used: Ethilenbis-ditiocarbamate of $\mathrm{Zn}$ (Zineb).
\end{abstract}

Index terms: fertilization, Citrus sinensis, Valencia orange productivity.

\section{INFLUENCIA DE Zn Y K EN EL TAMAÑO DEL FRUTO DE NARANJA VALENCIA}

RESUMEN - En plantaciones comerciales de naranjos, en Corrientes, Argentina, se observaron síntomas de deficiencia de zinc y frutos pequeños. Durante cuatro años (1995 a 1998), sobre plantas de naranja Valencia (C. sinensis, Osb.) injertadas sobre limón rugoso (C. jambhiri, Lush.), implantadas en 1974 en un suelo arenoso, se probaron seis tratamientos que variaron entre 1 y $3 \mathrm{~kg} . \mathrm{KCl}_{\text {.planta }}{ }^{-1}$.año $\mathrm{O}^{-1}$ (aplicados en abril y diciembre) con y sin zineb 80 (Ethilenbis-ditiocarbamato de Zn), 0,35\%.año ${ }^{-1}, 20$ L.planta ${ }^{-1},\left(13,3 \mathrm{~g} \mathrm{Zn}\right.$.planta ${ }^{-1}$ aplicado en diciembre). El diseño experimental utilizado fue de bloques completos al azar con cuatro repeticiones, parcela experimental una planta y sus borduras. Se tomaron muestras foliares todos los años en otoño y verano, determinándose las concentraciones foliares de Zn y K por espectrometría de absorción atómica. Las frutas cosechadas fueron clasificadas en pequeñas, medianas y grandes. Se realizó el análisis de Varianza, Test de Tukey y correlaciones de Pearson entre producción y concentraciones foliares. Altos niveles de fertilizaciones de K y Zn incrementaron la producción de frutas medianas y grandes (kg y porcentaje). Las concentraciones foliares de $\mathrm{K}$ y $\mathrm{Zn}$ fueron positivamente correlacionadas con producción de frutas grandes y medias y negativamente correlacionadas con frutas pequeñas.

Términos para indexación: fertilización, Citrus sinensis, naranja Valencia, productividad.

\section{INTRODUCTION}

The citrus species, as all vegetals, require essential elements to grow and produce, and their special susceptibility to minerals deficiencies is accepted. Excepting $\mathrm{Cl}$ and $\mathrm{Na}$ which deficiencies have not been described and $\mathrm{S}$ which deficiencies were detected only in hydroponics crops (Chapman y Brown, 1941), deficiencies of all mineral nutrients are frequently recognised in different situations (Aso, 1974; Malavolta, 1994).

Zinc deficiency is probably the most diffused nutritional alteration in all citric production areas. It is especially prevalent in sandy soils but also frequently in alkaline soils, and can be aggravated by high level of phosphate or nitrogen fertilization (Aso, 1974; Langthasa and Bhattacharyya, 1995). In general, soil or foliar zinc applications improve trees conditions and make deficiency symptoms decrease, although yield not always increase (Aso, 1974; Rodríguez et al., 1994). Fruits quality improvements (more saccharose contents, better rind texture) are reported (Langthasa and Bhattacharyya, 1991; Quin et al.,1996).

Potassium is a useful nutrient in citrus fertilization, it affects fruits production, size and quality. There are no much positive requests on production, but it is recognised as the most important element for citrus fruits quality (Alva and Tucker, 1999; Aso, 1974; Cohen, 1983; Quin et al.;1996). Its deficiency is nowadays associated with the citrus variegated chlorosis (Malavolta, 1994).

Variations in one nutrient supply affect the other elements levels, especially in light soils with low buffer power (Cohen, 1983). Chapman and Harding (1955) assume $\mathrm{Zn}$ and $\mathrm{Cu}$ deficiencies in some places in the USA due to $\mathrm{K}$ and $\mathrm{P}$ accumulation. $\mathrm{K}$ excess can cause $\mathrm{Zn}$ deficiency
(Del Rivero, 1968). According to Smith (1966), Zn applications increases foliar levels of K, but $\mathrm{K}$ applications do not affect $\mathrm{Zn}$ levels. Langthasa and Bhattacharyya (1995), found that $\mathrm{Zn}$ applications increase foliar concentrations of $\mathrm{N}$. Relationships between different mineral foliar concentrations have been studied, Martínez et al. (1995) found association between foliar levels of $\mathrm{Mn}, \mathrm{Cu}, \mathrm{Fe}$ and $\mathrm{Zn}$; Mazza et al. (1997) described positive correlation between foliar concentration of $\mathrm{Zn}$ and $\mathrm{K}$ when both nutrients were applied together and negative one when only $\mathrm{K}$ was supplied.

Argentine citrus production area seems to be rich in soils with potassium natural reserves. Experiences with $\mathrm{K}$ supply did not find effect on productivity, only a reduction on fruits number at high $\mathrm{K}$ levels (Aso, 1974). Citrus variegated chlorosis (C.V.C.), a disease found in Brazil in 1987 (Bar and Oren, 1992; Koizumi, 1995; Rosetti et al., 1991), was detected in Argentine in $1990^{(*)}$, caused by Xylella fastidiosa Wells et al. (Koizumi, 1995; Lee et al., 1993, Wells et al., 1987), in Corrientes, Argentine citrus area, produced small fruits size, of no commercial value, typical chlorosis on leaves and slow buds development (Raju and Wells, 1986). These symptoms are also associated with characteristics $\mathrm{Zn}$ and $\mathrm{K}$ deficiencies (Lima et al., 1996). C.V.C. is always related to low levels of K in leaves (Malavolta, 1994; Rodríguez et al., 1997). Zn and K supplies give better nutritional balance and increase fruits size (Martinez, et al., 1995; Rodriguez et al., 19974; Rodriguez et al., 1997).

To determine the effect on Valencia orange productivity and its relationships with foliar concentrations of $\mathrm{Zn}$ and $\mathrm{K}$, different levels of these nutrients were tested.

\footnotetext{
${ }^{1}$ (Trabalho 098/2004). Recebido: 03/08/2004. Aceito para publicação: 14/04/2005.

${ }^{2}$ Agricultural Engeneering.

${ }^{3}$ Magister of Science.

${ }^{4}$ Magister of Science.

${ }^{5}$ Magister.

Facultad de Ciencias Agrarias Universidad Nacional del Nordeste. Sarg. Cabral 2131 - 3400 - Corrientes - Argentina. Fax 543783 427131 .E-mail: mazza@ agr.unne.edu.ar

(*) Personal comunication J.P. Agostini and V.A. Rodríguez. 1990.
} 


\section{MATERIALS AND METHODS}

A Field work was placed in an orcharch with 312 trees. ha ${ }^{-1}$ at General Paz department, in Corrientes, Argentine. During four years (1995 to 1998), Valencia orange (C. sinensis) trees on Rough lemon (C. jambiri) rootstock, implanted in 1974, on an Udipsamment alfico soil were evaluated.

Experimental design was a randomized complete block with four replications, with a single tree and borders in the experimental plot. Treatment tested were: $\mathrm{T}_{1}: 1 \mathrm{~kg} \mathrm{KCl}$. tree $^{-1}$. $\mathrm{year}^{-1} ; \mathrm{T}_{2}: 2 \mathrm{~kg} \mathrm{KCl}$ tree $^{-1}$.year ${ }^{1} ; \mathrm{T}_{3}: 3 \mathrm{~kg} \mathrm{KCl}$.tree ${ }^{-1}$.year ${ }^{-1} ; \mathrm{T}_{4}: 1 \mathrm{~kg} \mathrm{KCl} \cdot$ tree $^{-1}$. year $^{-1}$ and Zineb 80, 0,35\%. year ${ }^{-1}\left(13,3\right.$ g Zn.tree ${ }^{-1}, 201$. tree $\left.^{-1}\right) ; \mathrm{T}_{5}: 2 \mathrm{~kg} \mathrm{KCl}$.tree ${ }^{-1}$.year ${ }^{-1}$ and Zineb 80, 0,35\%. year ${ }^{-1}\left(13,3 \mathrm{~g} \mathrm{Zn} \cdot\right.$ tree $^{-1}, 20$ 1.tree $\left.{ }^{-1}\right) ; \mathrm{T}_{6}: 3 \mathrm{~kg} \mathrm{KCl} \cdot$ tree $^{-1}$.year ${ }^{-1}$ and Zineb 80, 0,35\%. year $^{-1}\left(13,3\right.$ g Zn.tree ${ }^{-1}, 201 \cdot$ tree $\left.^{-1}\right)$.

Fertilization began in December of 1994. Zn applications were done in December. K doses were split in equal parts and applied in April and December each year. Standard fertilizations with $\mathrm{N}, \mathrm{P}, \mathrm{Ca}$ and $\mathrm{Mg}$ according to the normal practices in the region were done on all trees.

Foliar samples of fructiful branches were taken from the trees, according to the four cardinal points of equatorial trees zone every year (from 1995) in Autumn (March) and Summer (December). Zn and K concentrations were determined by atomic spectrum absorption (Ministry of Agriculture, Fisheries and Food, 1984).

Between October and December, fruits from each experimental plot were manually harvested and classified into small (less than $55 \mathrm{~mm}$ ), medium (between 55 and $65 \mathrm{~mm}$ ) and big (more than $65 \mathrm{~mm}$ ). Analyses of variance and Tukey test of harvest, fruit percentage of each category and foliar concentrations of $\mathrm{Zn}$ and $\mathrm{K}$ doses were performed. Pearson correlations between foliar levels and yield in percentage of each fruit size were calculated (Steel and Torrie, 1992). Statistical analyses were done with SPSS 8.0 (SPSS Base 8.0, 1998).

\section{RESULTSANDDISCUSSION}

The effects of different treatments in the harvested fruits can be observed since the second year (Table 1). In the total harvested fruit production, differences were detected only with the lower doses of $\mathrm{KCl}$, in 1997 and 1998, although variation between years is observed (Table 1). Treatments with the higher doses of $\mathrm{KCl}$ plus $\mathrm{Zn}$ presented higher production ( $\mathrm{kg}$ and percentage) of medium and big fruit size and less production (kg and percentage) of small fruit. Treatments with lower doses of $\mathrm{K}$ and specially ones without $\mathrm{Zn}$ showed higher production (kg and percentage) of small fruit size, just in 1997 and 1998. Foliar concentrations of $\mathrm{Zn}$ increased in the first year sample in the treatments with $\mathrm{Zn}$ supply, but in the following years became normal (Chapman, 1961). Foliar levels of $\mathrm{K}$ increased in treated plots (especially in the treatment with $3 \mathrm{~kg} \mathrm{KCl}$.tree ${ }^{-1}$.year-1 and Zineb 80, 0,35\%. year ${ }^{-1}(13,3 \mathrm{~g}$ Zn.tree ${ }^{-1}, 20$ L.tree $\left.^{-1}\right)$. This high level justify the excellent fruit size harvested (see Table 2). Foliar levels were higher in Summer than in Autumn, this was because the leaves sampled were three or four months old, and as $\mathrm{K}$ is a mobile nutrient, it concentrated most in the buds.

The effect of K supply (better when accompanied by Zn), could be seen in the increase of medium and big fruit production, specially in the last two years. In 1997 this effect appeared as the most important, probably because of the climatic conditions of the year. In this case it is necessary to evidence the variability showed by treatments with 1 and 2 $\mathrm{kg} \mathrm{KCl}$. tree $^{-1}$.year ${ }^{-1}$ and Zineb 80, 0,35\%. year $^{-1}$ (13,3 g Zn.tree ${ }^{-1}, 20$ L.tree ${ }^{1}$, and the stability of the treatment with $3 \mathrm{~kg} \mathrm{KCl} \cdot$ tree $^{-1}$.year ${ }^{-1}$ and Zineb 80, 0,35\%. year $^{-1}\left(13,3\right.$ g Zn.tree ${ }^{-1}, 20$ L.tree $\left.{ }^{-1}\right)$ (see Table 1).

Foliar concentrations of $\mathrm{K}$ in Autumn and Summer were positively correlated with the big size fruit production and percentage of the corresponding and the next year, just 1997 and 1998. Negative correlation between foliar levels of $\mathrm{K}$ and the small fruit production and

TABLE 1 - Total (tot) $\mathrm{kg}$ harvested started by categories small (sm), medium (md) and big (bg) by treatment (average of four replications) and by year.

\begin{tabular}{|c|c|c|c|c|c|c|c|}
\hline \multirow{2}{*}{ Year } & \multirow[b]{2}{*}{ Fruit size } & \multicolumn{6}{|c|}{ Treatment } \\
\hline & & 1 & 2 & 3 & 4 & 5 & 6 \\
\hline \multirow[t]{4}{*}{1995} & $\mathrm{sm}$ & $52.5 \mathrm{a}$ & $51.5 \mathrm{a}$ & $59.3 \mathrm{a}$ & $47.3 \mathrm{a}$ & $45.3 \mathrm{a}$ & $52.0 \mathrm{a}$ \\
\hline & $\mathrm{md}$ & $33.5 \mathrm{a}$ & $36.5 \mathrm{a}$ & $45.5 \mathrm{a}$ & $45.3 \mathrm{a}$ & $44.0 \mathrm{a}$ & $49.8 \mathrm{a}$ \\
\hline & bg & $27.8 \mathrm{a}$ & $19.3 \mathrm{a}$ & $28.0 \mathrm{a}$ & $21.0 \mathrm{a}$ & $22.8 \mathrm{a}$ & $35.0 \mathrm{a}$ \\
\hline & tot & $113.8 \mathrm{a}$ & $107.3 \mathrm{a}$ & $132.8 \mathrm{a}$ & $113.6 \mathrm{a}$ & $112.1 \mathrm{a}$ & $136.8 \mathrm{a}$ \\
\hline \multirow[t]{4}{*}{1996} & $\mathrm{sm}$ & $45.8 \mathrm{a}$ & $51.5 \mathrm{a}$ & $49.8 \mathrm{a}$ & $34.2 \mathrm{a}$ & $33.5 \mathrm{a}$ & $35.3 \mathrm{a}$ \\
\hline & md & $40.5 \mathrm{a}$ & $42.3 \mathrm{a}$ & $37.0 \mathrm{a}$ & $38.8 \mathrm{a}$ & $48.0 \mathrm{a}$ & $51.3 \mathrm{a}$ \\
\hline & bg & $26.5 \mathrm{a}$ & $32.0 \mathrm{ab}$ & $45.5 \mathrm{ab}$ & $32.8 \mathrm{ab}$ & $31.5 \mathrm{ab}$ & $53.5 \mathrm{~b}$ \\
\hline & tot & $112.8 \mathrm{a}$ & $125.8 \mathrm{a}$ & $132.3 \mathrm{a}$ & $105.8 \mathrm{a}$ & $113.0 \mathrm{a}$ & $140.1 \mathrm{a}$ \\
\hline \multirow[t]{4}{*}{1997} & $\mathrm{sm}$ & $33.0 \mathrm{a}$ & $29.3 \mathrm{ab}$ & $26.0 \mathrm{ab}$ & $31.3 \mathrm{a}$ & $19.8 \mathrm{ab}$ & $16.3 \mathrm{~b}$ \\
\hline & md & $25.3 \mathrm{a}$ & $26.3 \mathrm{a}$ & $32.8 \mathrm{a}$ & $26.5 \mathrm{a}$ & $28.5 \mathrm{a}$ & $27.0 \mathrm{a}$ \\
\hline & bg & 38.3 & $67.3 \mathrm{bc}$ & $80.5 \mathrm{~b}$ & $65.8 \mathrm{bc}$ & $92.3 \mathrm{ab}$ & $112.8 \mathrm{a}$ \\
\hline & tot & $96.6 \mathrm{a}$ & $122.9 \mathrm{ab}$ & $139.3 \mathrm{~b}$ & $123.6 \mathrm{ab}$ & $140.6 \mathrm{~b}$ & $156.1 \mathrm{~b}$ \\
\hline \multirow[t]{4}{*}{1998} & $\mathrm{sm}$ & $32.0 \mathrm{ab}$ & $44.5 \mathrm{a}$ & $40.5 \mathrm{ab}$ & $24.0 \mathrm{ab}$ & $37.3 \mathrm{ab}$ & $19.8 \mathrm{~b}$ \\
\hline & md & $27.5 \mathrm{~b}$ & $41.5 \mathrm{a}$ & $25.0 \mathrm{~b}$ & $30.5 \mathrm{ab}$ & $32.0 \mathrm{ab}$ & $30.8 \mathrm{ab}$ \\
\hline & bg & $36.8 \mathrm{~b}$ & $44.5 \mathrm{~b}$ & $43.0 \mathrm{~b}$ & $45.5 \mathrm{~b}$ & $44.5 \mathrm{~b}$ & $82.3 \mathrm{a}$ \\
\hline & tot & $96.3 \mathrm{a}$ & $130.5 \mathrm{~b}$ & $108.5 \mathrm{ab}$ & $100.0 \mathrm{a}$ & $113.8 \mathrm{ab}$ & $132.9 \mathrm{~b}$ \\
\hline
\end{tabular}

Averages with the same letter in the row don ${ }^{\star} t$ have significantly differences, according with Tukey test at 5\% significance level.

TABLE 2 - Foliar concentrations of $\mathrm{Zn}\left(\mathrm{mg}^{\mathrm{kg}} \mathrm{kg}^{-1}\right)$ and $\mathrm{K}\left(\mathrm{g} . \mathrm{kg}^{-1}\right)$, averages of four replications by treatments in Autumn (A) and Summer (S) foliar samples.

\begin{tabular}{|c|c|c|c|c|c|c|c|c|c|c|c|c|c|c|}
\hline \multirow{3}{*}{ Treat. } & \multicolumn{4}{|c|}{1995} & \multicolumn{4}{|c|}{1996} & \multicolumn{4}{|c|}{1997} & \multicolumn{2}{|c|}{1998} \\
\hline & \multicolumn{2}{|c|}{$\mathrm{Zn}$} & \multicolumn{2}{|c|}{$\overline{\mathrm{K}}$} & \multicolumn{2}{|c|}{$\mathrm{Zn}$} & \multicolumn{2}{|c|}{$\mathrm{K}$} & \multicolumn{2}{|c|}{$\mathrm{Zn}$} & \multicolumn{2}{|c|}{$\mathrm{K}$} & \multirow{2}{*}{$\begin{array}{c}\mathrm{Zn} \\
\mathrm{A}\end{array}$} & \multirow{2}{*}{$\begin{array}{l}\mathrm{K} \\
\mathrm{A}\end{array}$} \\
\hline & A & $\mathrm{S}$ & A & S & A & $\mathrm{S}$ & A & S & A & $\mathrm{S}$ & A & S & & \\
\hline 1 & 17.5 & 42.8 & 10.8 & 11.7 & 74.4 & 26.4 & 11.8 & 12.7 & 27.5 & 20.8 & 9.0 & 9.8 & 15.5 & 8.2 \\
\hline 2 & 18.0 & 58.9 & 11.3 & 13.6 & 68.8 & 29.3 & 7.4 & 14.2 & 28.8 & 20.0 & 11.0 & 10.4 & 14.2 & 8.2 \\
\hline 3 & 16.2 & 50.0 & 12.6 & 13.2 & 50.0 & 24.5 & 11.7 & 19.8 & 28.8 & 19.2 & 11.0 & 12.3 & 13.0 & 10.9 \\
\hline 4 & 55.7 & 58.9 & 13.5 & 13.2 & 59.3 & 28.3 & 8.5 & 13.5 & 35.0 & 27.7 & 9.5 & 8.8 & 27.5 & 9.3 \\
\hline 5 & 49.7 & 53.6 & 21.3 & 13.5 & 55.4 & 28.3 & 10.1 & 21.0 & 38.0 & 30.0 & 12.1 & 11.6 & 28.4 & 9.8 \\
\hline 6 & 47.2 & 57.1 & 21.0 & 16.0 & 58.4 & 28.3 & 14.3 & 30.6 & 37.0 & 28.4 & 14.5 & 16.2 & 26.3 & 14.8 \\
\hline
\end{tabular}


TABLE 3 - Pearson Correlation Coefficients (r) between foliar concentrations of K in Autumn and Summer and big and small fruit productions (Kg and percentage) and their probabilities (p).

\begin{tabular}{|c|c|c|c|c|c|c|c|c|c|c|}
\hline & & & \multicolumn{4}{|c|}{ Big fruit size } & \multicolumn{4}{|c|}{ Small fruit size } \\
\hline & & & \multicolumn{2}{|c|}{$\mathrm{Kg}$} & \multicolumn{2}{|c|}{$\%$} & \multicolumn{2}{|c|}{$\mathrm{Kg}$} & \multicolumn{2}{|c|}{$\%$} \\
\hline & & & Same year & Next year & Same year & Next year & Same year & Next year & Same year & Next year \\
\hline \multirow[t]{4}{*}{1995} & Autumn & $\mathrm{r}$ & --------- & -0.01 & --------- & 0.05 & --------- & 0.02 & --------- & 0.16 \\
\hline & & $\mathrm{p}$ & & 0.9892 & & 0.8304 & & 0.9466 & & 0.4663 \\
\hline & Summer & $\mathrm{r}$ & --------- & 0.27 & --------- & 0.04 & ---------- & 0.24 & --------- & 0.14 \\
\hline & & $\mathrm{p}$ & & 0.2159 & & 0.8684 & & 0.2665 & & 0.5245 \\
\hline \multirow[t]{4}{*}{1996} & Autumn & $\mathrm{r}$ & 0.40 & -0.0002 & 0.25 & -0.03 & 0.04 & -0.12 & -0.12 & -0.09 \\
\hline & & $\mathrm{p}$ & 0.0585 & 0.9992 & 0.2471 & 0.8849 & 0.8451 & 0.5896 & 0.5942 & 0.6949 \\
\hline & Summer & $\mathrm{r}$ & -0.11 & 0.38 & -0.23 & 0.40 & 0.08 & -0.32 & 0.070 .7535 & $-0.42 *$ \\
\hline & & $\mathrm{p}$ & 0.6259 & 0.0744 & 0.2998 & 0.0601 & 0.7086 & 0.1420 & & 0.0435 \\
\hline \multirow[t]{4}{*}{1997} & Autumn & $\mathrm{r}$ & 0.40 & $0.54 *$ & 0.160 .4573 & $0.57 *$ & 0.17 & $-0.53 *$ & -0.16 & $-0.59 *$ \\
\hline & & $\mathrm{p}$ & 0.0568 & 0.0078 & & 0.0047 & 0.4426 & 0.0091 & 0.4649 & 0.0030 \\
\hline & Summer & $\mathrm{r}$ & $0.57 *$ & $0.61^{*}$ & 0.380 .0706 & $0.66 *$ & -0.20 & $-0.53 *$ & $-0.53 *$ & $-0.56 *$ \\
\hline & & $\mathrm{p}$ & 0.0045 & 0.0020 & & 0.0006 & 0.3563 & 0.0091 & 0.0087 & 0.0051 \\
\hline \multirow[t]{4}{*}{1998} & Autumn & $\mathrm{r}$ & $0.58 *$ & --------- & $0.59 *$ & --------- & $-0.49 *$ & --------- & $-0.48 *$ & --------- \\
\hline & & $\mathrm{p}$ & 0.0036 & & 0.0029 & & 0.0170 & & 0.0190 & \\
\hline & Summer & $\mathrm{r}$ & $0.60 *$ & --------- & $0.63 *$ & --------- & $-0.64 *$ & --------- & $-0.61 *$ & --------- \\
\hline & & $\mathrm{p}$ & 0.0024 & & 0.0014 & & 0.0010 & & 0.0020 & \\
\hline
\end{tabular}

Coefficients with $(*)$ are significant $(\alpha=0.05)$.

TABLE 4 - Pearson Correlation Coefficients (r) between foliar concentrations of $\mathrm{Zn}$ in Autumn and Summer and big and small fruit productions (Kg and percentage) and their probabilities (p).

\begin{tabular}{|c|c|c|c|c|c|c|c|c|c|c|}
\hline & & & \multicolumn{4}{|c|}{ Big fruit size } & \multicolumn{4}{|c|}{ Small fruit size } \\
\hline & & & \multicolumn{2}{|c|}{$\mathrm{Kg}$} & \multicolumn{2}{|c|}{$\%$} & \multicolumn{2}{|c|}{$\mathrm{Kg}$} & \multicolumn{2}{|c|}{$\%$} \\
\hline & & & Same year & Next year & Same year & Next year & Same year & Next year & Same year & Next year \\
\hline \multirow[t]{2}{*}{1995} & Autumn & $\mathrm{r}$ & ---------- & 0.220 .3107 & ---------- & 0.090 .6553 & ---------- & -0.130 .5580 & ---------- & -0370.0758 \\
\hline & Summer & $\begin{array}{l}\mathrm{p} \\
\mathrm{r} \\
\mathrm{p}\end{array}$ & ---------- & $\begin{array}{l}-0.004 \\
0.9851\end{array}$ & ---------- & -0.090 .6638 & ---------- & -0.070 .7440 & ---------- & -0.080 .6943 \\
\hline \multirow[t]{2}{*}{1996} & Autumn & $\mathrm{r}$ & 0.150 .4812 & 0.130 .5431 & -0.020 .9297 & -0.080 .6981 & 0.110 .6150 & 0.080 .6942 & 0.040 .8657 & -0.170 .4259 \\
\hline & Summer & $\begin{array}{l}\mathrm{p} \\
\mathrm{r} \\
\mathrm{p}\end{array}$ & $\begin{array}{l}-0.14 \\
0.5153\end{array}$ & 0.130 .5419 & -0.010 .9475 & 0.090 .6595 & -0.370 .0768 & -0.180 .4093 & -0.380 .0689 & -0.240 .2623 \\
\hline \multirow[t]{2}{*}{1997} & Autumn & $\begin{array}{l}\mathrm{r} \\
\mathrm{p}\end{array}$ & -0.350 .0962 & $\begin{array}{l}-0.54 * \\
0.0066\end{array}$ & -0.300 .1527 & $\begin{array}{l}-0.47 * \\
0.0206\end{array}$ & 0.090 .6688 & $\begin{array}{l}0.44 * \\
0.0330\end{array}$ & 0.260 .2145 & $\begin{array}{l}0.61 * \\
0.0017\end{array}$ \\
\hline & Summer & $\begin{array}{l}\mathrm{r} \\
\mathrm{p}\end{array}$ & $\begin{array}{lll}-0.08 & 0.7237\end{array}$ & 0.240 .2538 & 0.020 .9120 & 0.270 .2086 & -0.310 .1371 & -0.110 .6221 & -0.220 .3068 & $\begin{array}{l}-0.12 \\
0.5706\end{array}$ \\
\hline 1998 & $\begin{array}{l}\text { Autumn } \\
\text { Summer }\end{array}$ & $\begin{array}{l}\mathrm{r} \\
\mathrm{p} \\
\mathrm{r} \\
\mathrm{p}\end{array}$ & $\begin{array}{l}0.59 * \\
0.0026 \\
0.57 * \\
0.0037\end{array}$ & ---------- & $\begin{array}{l}0.62 * \\
0.0012 \\
0.55 * \\
0.053\end{array}$ & ---------- & $\begin{array}{c}-0.44 * \\
0.0299 \\
-0.41 * \\
0.0446\end{array}$ & ----------- & $\begin{array}{c}-0.54 * \\
0.0070 \\
-0.49 * \\
0.0145\end{array}$ & --------- \\
\hline
\end{tabular}

Coefficients with $(*)$ are significant $(\alpha=0.05)$.

percentage was detected. It indicates that this concentrations are good predictors of the future harvest quality (Table 3) to 1997 and 1998. Foliar levels of $\mathrm{Zn}$ are not always correlated with the production, indicating that there is no significantly association between these variables, therefore foliar concentration of $\mathrm{Zn}$ cannot be considered good predictor of fruit quality (Table 4)

\section{REFERENCES}

ALVA, A.K.; TUCKER, D.P.H. Soil and citrus nutrition. In: TIMMER L.W.; DUNCAN, L.W. (Ed.) Citrus health management. Gainsville: University of Florida, 1999. v.6, p.59-71.

ASO, P.J. Conocimientos acerca de la fertilización de los citrus y resultados obtenidos en la argentina. In: REUNIÓN NACIONAL DE FERTILIDAD Y FERTILIZANTES, 2., 1974, Buenos Aires. p.172185.

BAR JOSEPH, M.; OREN, J. Virus, viroid and mycoplasm diseases of citrus. Hassadeh, Israel, v.72, n.8, p.979-983, 1992.

CHAPMAN, H.D. The status of present criteria for the diagnosis of nutrient conditions on citrus. In: REUTHER, W. (Ed.). Plant analysis and fertilizers problems. Washington: American Institute Biological Science, 1961.

CHAPMAN, H.D.; BROWN, S.M. The effect of phosphorus deficiency in citrus. Hilgardia, Oakland, v.14, p.161-181, 1941.

CHAPMAN, H.D.; HARDING, R.B. What is happening to our citrus soils?. California Citrograph, Los Angeles, v.40, n.6, p.207, 222226, 1955.

COHEN, A. Fertilización de los cítricos. Suiza: Instituto Internacional de la Potasa, 1983. p12-18. (Boletín IIP, 4)

DEL RIVERO, J.M. Los estados de carencia de los agrios. Madrid: Mundi-Prensa, 1968. p.131-133.

ESPANHA. Ministry of Agriculture, Fisheries and Food. Técnicas de análisis de vegetales, piensos y aguas. España: Academia León, 1984. p68-136.

KOIZUMI, M. Virus or virus-like diseases of citrus in tropical and subtropical zones. JIRCAS International Symposium Series, Tsukuba, n.3, p.61-66, 1995.

LANGTHASA, S.; BHATTACHARYYA, R.K. Foliar application of zinc on fruit quality of Assam Lemon (Citrus limon Burn). South-Indian Horticulture, Tamil Nadu, v.39, n.3, p.153-155, 1991. 
LANGTHASA, S.; BHATTACHARYYA, R.K. NPK contents of Assam lemon leaf affected by foliar zinc sprays. Annals of Agricultural Research, New Delhi, v.16, n.4, p.493-494, 1995.

LEE, R.F.; BERETTA, M.J.G; HARTUNG, J.H.; HOOKER, M.E.; DERRICK, K.S. Citrus variegated chlorosis: confirmation of a Xilella fastidiosa as the causal agent. Summa Phytopathogica, Botucatu, v.19, p.123$125,1993$.

LIMA, J.E.O.; COUTINHO, A.; ROBERTO, S.R.; MIRANDA, V.S.; CARLOS, E.F.; SALVA, R.; MASSARI C. New developments on citrus variegated chlorosis research at Fundecitrus, Brazil. In: CONGRESS OF THE INTERNATIONAL SOCIETY OF CITRICULTURE, 8., 1996, Nelspruit. Proceedings... v.1, p.435-439.

MALAVOLTA, E. Leaf analysis in Brazil - present and prespectives. In: International Citrus Congress, 7., 1992, Acireale, Italy. Proceedings... Acireale: International Society of Citriculture, 1994. p.570-574.

MARTÍNEZ, GC.; V.A. RODRIGUEZ, S.M. Mazza de Gaiad. Relevamiento de las concentraciones de $\mathrm{Cu}, \mathrm{Mn}, \mathrm{Fe}$ en naranja (Citrus sinensis $\mathrm{L}$ ), var. Valencia Late tratada con diferentes niveles de Zn. Hort. Arg., v.14, n.37, p.1-6, 1995.

MAZZA, S.M.; MARTÍNEZ, G.C.; RODRIGUEZ, V.A. Comportamiento de las concentraciones foliares de $\mathrm{Zn}$ y $\mathrm{K}$ y sus asociaciones en naranjo Valencia late (Citrus sinensis,L). Hort Arg., v.16, n.40-41, p.1-4, 1997.

QUIN, X.N. Foliar spray of $\mathrm{B}, \mathrm{Zn}$ and $\mathrm{Mg}$ and their effects on fruit production and quality of Jincheng orange (Citrus sinensis). Journal of Southwest Agriculture University, v.18, n.1, p.40-45, 1996.

QUIN-X.N.; YIN, K.L; TANG, J.Y.; LIU, W.; HE, S. G. The role of potassium in preventing leaf drop and improving fruit yield and quality of lemon (Citrus lemon, B). Journal of Southwest Agriculture
University, v.18, n.1, p.20-23. 1996.

RAJU, B.C.; WELLS, J.M. Diseases caused by fastidious xylem-limited. Plant Diseases, St Paul, v.70, n.3, p.182-186, 1986.

RODRÍGUEZ, V.A.; MARTÍNEZ, G.C.; MAZZA DE GAIAD, S.M. Aplicaciones foliares de $\mathrm{Zn}$ en naranjo (Citrus sinensis), var valencia late: absorción mensual e influencia en la productividad. Hort. Arg, v.13. n.34-35, p.61-65, 1994.

RODRÍGUEZ, V.A.; MARTÍNEZ,G.C.; MAZZA, S.M. Influencia de Zn y $\mathrm{K}$ en la productividad de naranja valencia. In: CONGRESO ARGENTINO DE HORTICULTURA, 20., 1997, Bahia Blanca. Abstracts... Bahia Blanca: Universidad Nacional del Sur, 1997. p.171.

ROSETTI, V.; GARNIER, M.; BOVÉ, J.M.; BERETTA, M.J.G.; TEIXEIRA, A.R.R.; QUAGGIO, J.A.; DENEGIR, D. Ocurrence of xylem-restricted bacteria in sweet orange trees affected with chlorosis variegation, a new disease in Brazil. FAO Plant Protection Bulletin, Rome, v.39, p.115-166, 1991.

SMITH, P.F. Leaf analysis of citrus in nutrition of fruit crops. In: CHILDERS, N.F. (Ed.). Nutrition of fruit crops: temperate to tropical fruit. New Brunswick: Rutgers The State University, 1966. p.174207.

SPSS Base 8.0. Manual del usuario del Spss Base 8.0 para Windows. Chicago: Marketing Department SPSS, 1998.

STEEL, R.G.D.; TORRIE, J.H. Bioestadística: principios y procedimientos. $2^{\text {nd }}$ ed. New York: Mc Graw Hill, 1992. 622 p.

WELLS, J.M.; RAJU, B.C.; HUNG H.Y.; WEISBURG, W.G.; MADELCOPAUL, L.; BRENER, D.J. Xilella fastidiosa gen. nov., sp. nov.: Gramnegative, xylem-limited, fastidious plant bacteria related to Xanthomonas spp. International Journal of Systematic Bacteriology, Washington, v.37, p.136-143, 1987. 